\title{
APPLICATION POTENTIAL OF SUGAR CANE AND RICE BAGASSE IN THE REMOVAL OF CONTAMINANTS PRESENT IN THE OIL PRODUCED WATER
}

\section{POTENCIAL DE APLICAÇÃO DO BAGAÇO DA CANA-DE-AÇÚCAR E DO ARROZ NA REMOÇÃO DE CONTAMINANTES PRESENTES NA ÁGUA PRODUZIDA DE PETRÓLEO}

\author{
M. A. CAVAlCANTE, ,, L. M. de M. MARQUES ${ }^{1}$, F. D. de S. JUNIOR ${ }^{1}$, K. R. A. PEREIRA¹, K. R. S. \\ FAGUNDES ${ }^{2}$ and F. P. FAGUNDES ${ }^{1}$
}

${ }^{1}$ Universidade Potiguar, Mossoró, Rio Grande do Norte, Brasil

${ }^{2}$ Universidade Federal Rural do Semi-Árido, Mossoró, Rio Grande do Norte, Brasil

${ }^{*}$ Corresponding author. Universidade Potiguar, Mossoró, Rio Grande do Norte, Brasil, Phone: +55 084998096464

e-mail addressl: mayraacavalcante@hotmail.com (M. A. Cavalcante).

\section{A R T I C L E I N F O}

Article history:

Received 2018-10-10

Accepted 2018-12-20

Available online 2019-04-25

palavras-chave

Bagaço de cana-de-açúcar

Bagaço de arroz

Processo de adsorção

Água produzida

keywords

Sugarcane bagasse

Rice husk

Adsorption process

Produced water

\begin{abstract}
A B S T R A C T
Despite the huge advances made in the petroleum sector regarding the innovation of its technological processes, there are still some troubling problems. An example of this refers to the water produced. Treatment and disposal have become one of the biggest challenges in the oil industry. The problem consists in the difficulty of degradation of the compounds to an adequate level that allows the safe disposal in the environment, ensuring the possibility of reuse or disposal in the standards established by the environmental agencies. This fact has encouraged researchers to direct studies to find alternatives capable of efficiently removing the contaminants present in this water at a lower cost compared to other existing technologies. Thus, the purpose of this work is to use adsorbent materials with high porosity and high silica content, such as sugarcane bagasse and rice, in order to remove the crude oil content present in the water produced. The adsorption process of the crude oil on the surface of each support occurred at predetermined intervals and with different concentrations of contaminant and adsorbent. A factorial modeling mapping $\left(3^{2}\right)$ was performed to evaluate the effect of the interactions between the concentrations of each support in relation to the contaminant. From the results obtained, it was verified that the calcination of sugarcane bagasse and rice was fundamental for the efficiency of the system. In all the systems an increase of the percentage of removal using these adsorbents was observed, suggesting that both represent a promising application in the advance of technologies responsible for the treatment of the water produced.
\end{abstract}

R E S U M O

Apesar dos imensos avanços ocorridos no setor petrolífero quanto à inovação de seus processos tecnológicos, ainda existem alguns problemas preocupantes. Um exemplo disso refere-se à água produzida. O tratamento e descarte tem se tornado um dos maiores desafios do setor petrolífero. A problemática consiste na dificuldade de degradação dos compostos até um nível adequado que permita o descarte seguro no meio ambiente, assegurando a possibilidade de reutilização ou descarte nos padrões estabelecidos pelos órgãos ambientais. Esse fato tem incentivado pesquisadores a direcionar estudos para encontrar alternativas capazes de remover de forma eficiente os contaminantes presentes nessa água com um custo inferior comparado às demais tecnologias existentes. Assim, esse trabalho tem por finalidade utilizar materiais adsorventes de alta porosidade e com alto teor de sílica, como o bagaço da cana-de-açúcar e de arroz, com o intuito de remover o teor de óleo cru presente na água produzida. O processo de adsorção do óleocru na superfície de cada suporte ocorreu em intervalos pré-estabelecidos e com concentrações de contaminante $e$ adsorvente diferentes. Foi realizado um mapeamento por modelagem fatorial $\left(3^{2}\right)$ para avaliar o efeito das interações ocorridas entre a concentração de cada suporte em relação 
ao contaminante. A partir dos resultados obtidos, foi verificado que a calcinação do bagaço de cana-de-açúcar e do arroz foi fundamental para eficiência do sistema. Em todos os sistemas foi observado um aumento do percentual de remoção utilizando esses adsorventes, sugerindo que ambos representam uma aplicação promissora no avanço de tecnologias responsáveis pelo tratamento da água produzida.

\section{INTRODUCTION}

Since the implementation and consolidation of oil as a global energy matrix, the oil industry has been seeking to perfect its processes for the purpose of maintaining profitability and the environment. Despite the huge advances in the petroleum sector linked to its technological processes, there are still some troubling problems, such as the water produced, which consists of all contaminated water present in the exploration and production of hydrocarbons, heavy metals, oil and gas emulsified, in addition to other compounds. The treatment and disposal of this water has become one of the biggest challenges in the oil industry today (AHMADUN et.al., 2013).

Adsorption using low cost adsorbents is currently recognized as an efficient, economical and low energy consumption method for the decontamination of the water (PANDEY, et al., 2000). Among the numerous materials used for the removal of contaminants, those of renewable origin have attracted a great deal of attention. Bagasse from industrial waste. The industrial waste bagasse have received great attention due to their physico-chemical properties such as porosity and quantity of functional groups capable of physically and chemically binding to pollutants.

Sugarcane and rice have been increasingly prominent on the world stage because they are highly efficient raw materials for the production of biofuels and the generation of vegetable oil, respectively. The high production of these inputs generates an enormous amount of residue, in which there is the possibility of applying these wastes as adsorbent materials for treatment of effluents, due to the high concentration of silanols present (LUZ, 2009). In this context, the present study aims to evaluate the potential of sugarcane bagasse and rice as adsorbent materials for the removal of contaminants from the produced water. In parallel, map by response surface, using the software Statistica 7.0, the main variables responsible for promoting the efficiency of the adsorption process.

\section{METHODOLOGY}

\subsection{Materials}

The bagasse from sugarcane and rice were purchased from the region of Mossoró/ RN/ Brazil and stored at $25^{\circ} \mathrm{C}$ for subsequent purification. The oil was sold by Petrobras from the region of Canto do Amaro UO RN / CE. The other reagents were all used from analytical grade.

\subsection{Methodology}

The experiment was carried out in the following sequence: sugarcane bagasse and rice, characterization of the same by $\mathrm{x}$-ray fluorescence (in natura purified, in natura calcined), adsorption test (isotherm construction), mapping by factorial modeling (Statistica 7.0 software).

\subsection{Characterization of Petroleum}

Crude oil was used as raw material. The API grade range of this oil was $22-23^{\circ}$ with absolute density of 920.97 $\mathrm{kg} / \mathrm{m}^{3}$ at $25^{\circ} \mathrm{C}$ using a $4200 \mathrm{M}$ DMA equipment.

\subsection{Distribution of Particle Size}

The relative distribution of the particle size of the grains resulting from the crushing of the sugarcane bagasse and rice was carried out by dry sieving. The sample was subjected to vibration for 15 minutes in a set of sieves of previously chosen apertures (100 mesh) as a function of the material, employing a mechanical stirrer.

\subsection{Bagasse Purification}

The inputs derived from sugar cane and rice were purified using the method developed by Rodrigues et al. (2009). According to the authors, a pre-established amount of bagasse was kept under constant stirring in aqueous sodium hydroxide solution $(0.25 \mathrm{~mol} / \mathrm{L})$ for 24 hours. Subsequently, this mixture was filtered and washed with distilled water to remove the soluble impurities. After this process, the bagasse was washed with distilled water and dried at $105^{\circ} \mathrm{C}$ for 12 hours.

\subsection{Bagasse Calcining}

The bagasse was calcined at a temperature of $300{ }^{\circ} \mathrm{C}$ for 2 hours with batch of 10 grams of input in a mufla model $305 \mathrm{C}$ from Shimadzu.

\subsection{Determination of oil / hexane stability}

Stability tests were performed based on the degradation kinetics of the sample over predetermined times in the presence of atmospheric air and light. Aliquots of $3 \mathrm{ml}$ were removed from the initial solution (petroleum / hexane) and evaluated in the UV spectrophotometer $(340 \mathrm{~nm})$ for a pre-established period: 30, 60, 120, 180, 240, 300, 360, 420, 480 and 1440 minutes.

\subsection{Mapping of The Adsorption Process by Factorial}

Response surfaces were used to examine the relationships between one or more variables and a quantitative set of experimental factors. These statistical methods were employed after a screening of the important factors, which is usually performed previously by a factorial design. After that, it was necessary to find one of the levels of factors that maximize the response variable (removal efficiency). To study the mapping of the variables of the adsorption process of the oil on the surface of each adsorbent, a factorial design of 32 was used for each system: three levels with two variables, as can be seen in Table 1 . 
Table 1 - Factorial planning adopted according to the levels and variables studied.

\begin{tabular}{|c|c|c}
\multicolumn{2}{|c}{ Variables } & Level \\
\hline \multirow{4}{*}{ Sugar cane } & $\begin{array}{c}\text { Concentration of } \\
\text { adsorbate }(\%)\end{array}$ & $2(-1)-4(0)-6(+1)$ \\
\cline { 2 - 3 } & $\begin{array}{c}\text { Concentration of } \\
\text { adsorbent }(\mathrm{g} / 25 \mathrm{~mL})\end{array}$ & $\begin{array}{c}0,5(-1)-1,25(0)-2 \\
(+1)\end{array}$ \\
\hline \multirow{3}{*}{ Rice husk } & $\begin{array}{c}\text { Concentrationofadsorbate } \\
(\%)\end{array}$ & $2(-1)-4(0)-6(+1)$ \\
\cline { 2 - 3 } & $\begin{array}{c}\text { Concentration of } \\
\text { adsorbent }(\mathrm{g} / 25 \mathrm{~mL})\end{array}$ & $\begin{array}{c}0,5(-1)-1,25(0)-2 \\
(+1)\end{array}$ \\
\hline
\end{tabular}

Factor levels were coded as -1 (low), 0 (center point) and 1 (high). For data treatment, the statistical program Statistica Software version 7.0 was used to obtain the effects, coefficients and response surfaces.

\section{RESULTS AND DISCUSSION}

\subsection{Purification of samples}

After the washing of the bagasse with the alkaline $\mathrm{NaOH}$ solution $(0.25 \mathrm{~mol} / \mathrm{L})$ and intercalated with distilled water, the supernatant was removed for reading in the spectrophotometer (wavelength 340 and $640 \mathrm{~nm}$ ) in order to evaluate the purification efficiency. The results indicated that after contact the washes were responsible for an absorbance close to 0 , indicating, therefore, the process efficiency for adsorbents of sugarcane bagasse and rice in hexane.

\subsection{System Stability Tests}

Before starting the adsorption tests inherent to each adsorbent, the stability of the contaminant (crude oil) in hexane was evaluated as a function of time. Every 30 minutes a sample of this mixture was removed and then read using a spectrophotometer in the UV-Visible region (Wavelength 340 $\mathrm{nm}$ ). The absorbance values as a function of time (system: 25 $\mathrm{mL}$ hexane $+4 \%$ crude oil). These values were practically constant and there were no external interferences in the result of the process, characterizing the stability of the solution and implying that any alteration in the supernatant concentration will occur due to the interaction with the support.

\subsection{Influence of the purification process on the removal efficiency of contaminants}

A factorial model was developed where it was possible to evaluate the effect of the interactions of these variables (adsorbate concentration and adsorbent concentration) on the efficiency of the process of removal of the contaminant from the medium and Figure 1 shows the results of the removal
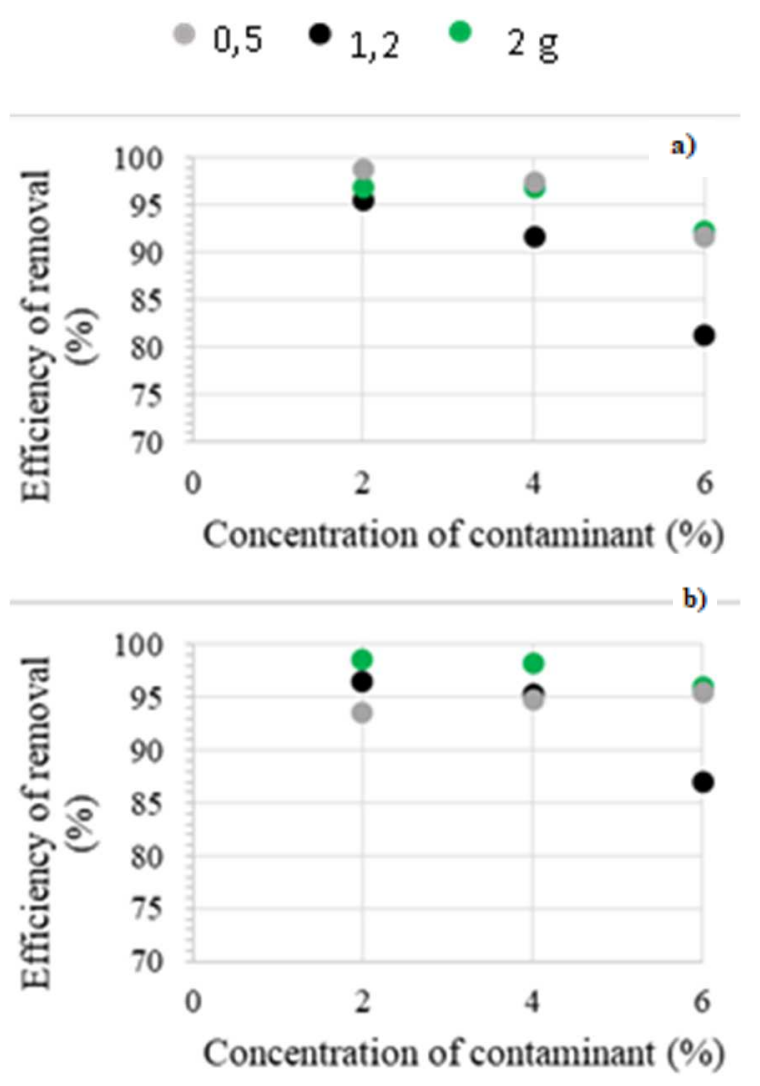

Figure 1- Efficiency of removal as a function of contaminant concentration for each concentration of purified sugar cane bagasse (a) in natura purified (b) in natura calcinated.

The interaction of the contaminant with the bagasse in calcined in natura was higher compared to the purified in natura bagasse at the concentrations of contaminant and adsorbent studied, as can be seen in the graphs of Figure 1 (a) and 1 (b). However, this efficiency was not accentuated due to the need to purify the support, prior to the calcination process. This fact would possibly increase the interaction potential of this support with the groups present in the contaminants. Furthermore, it is noted that the increase in the removal efficiency of the support is not proportional to the increase in its concentration in the medium. This can be explained due to the competitive effect of the bagasse particles that tend to get less and less dispersed in the medium and, thus, to promote a greater interparticle interaction with reduction of surface area. According to the data presented the system containing $2 \%$ of contaminant $+0.5 \mathrm{~g}$ of purified bagasse was responsible for a $99 \%$ efficiency of removal. In the calcined system, the concentration of $1.25 \mathrm{~g}$ of calcined bagasse was responsible for the higher removal efficiency, since the calcination process favors the dispersion process (RUTHEVEN, 1984).

Figure 2 shows the graphs referring to the process efficiencies using in natura purified (a) and in natura calcined (b) inorganic rice bagasse supports respectively. 

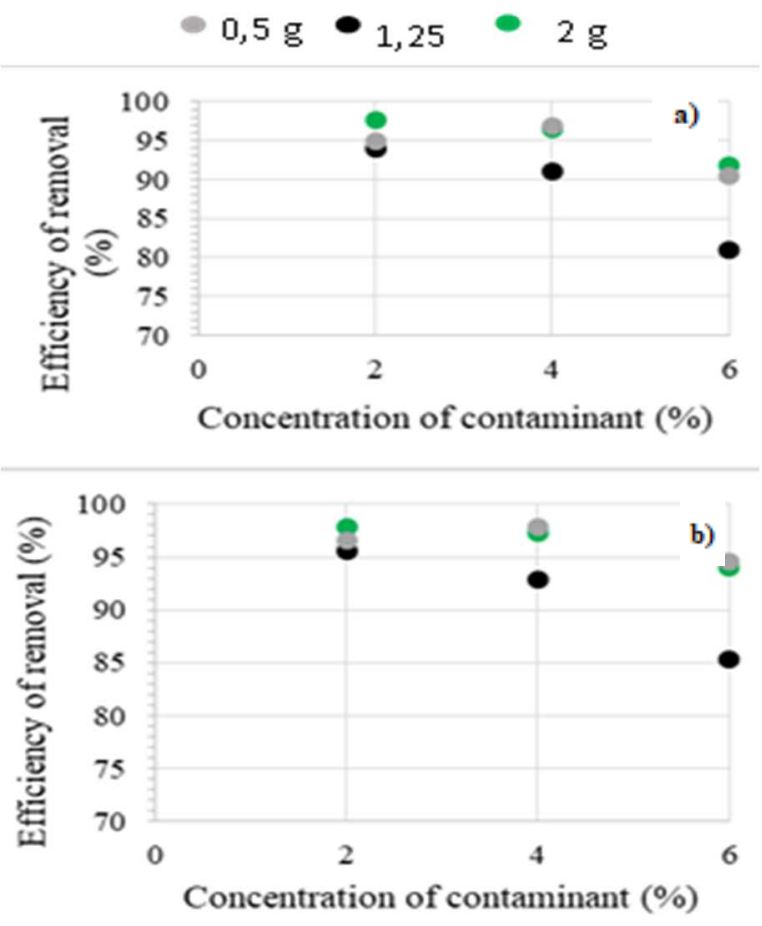

Figure 2 - Efficiency of removal using the rice bagasse supports (a) purified in natura and (b) calcined in natura.

The calcined in-rice bagasse system shows a $98 \%$ removal result with $0.5 \mathrm{~g}$ of ash and $6 \%$ of contaminant. This high percentage of oil removal by ash from calcined rice cake can be justified due to the strong interaction of the silanols (compounds with the structure formed by silicon and hydroxyl) with the petroleum derivatives, including phenol.

\subsection{Mapping of the adsorption process by factorial modeling}

Through the factorial modeling it was possible to map the effect of the interactions of the variables (adsorbate concentration and ideal adsorbent) on the efficiency of the process of removal of the contaminant from the medium. Figure 3 shows the response surfaces of the removal percentage $(\%)$ as a function of the contaminant concentration versus the concentration of the sugar cane bagasse in natura (a) and purified (b), respectively.

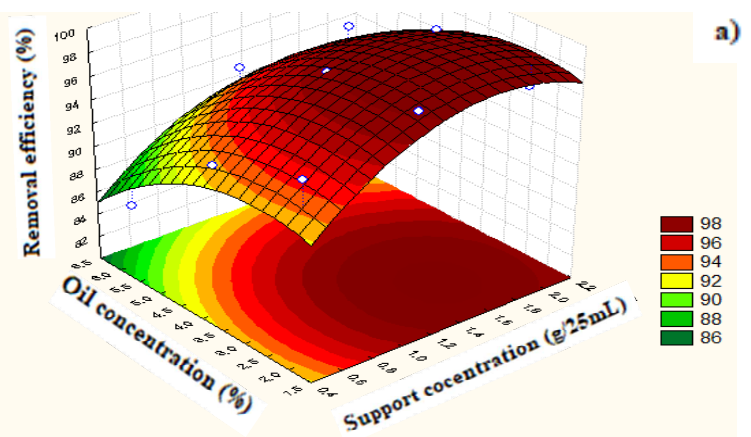

a)

$$
\begin{gathered}
Z=39,86-335,42 x+278,72 x^{2}+279,41 y+48,62 y^{2}+954,04 x \cdot y- \\
165,26 x \cdot y^{2}-99,58 \cdot x^{2} \cdot y+137,68 x^{2} \cdot y^{2}
\end{gathered}
$$

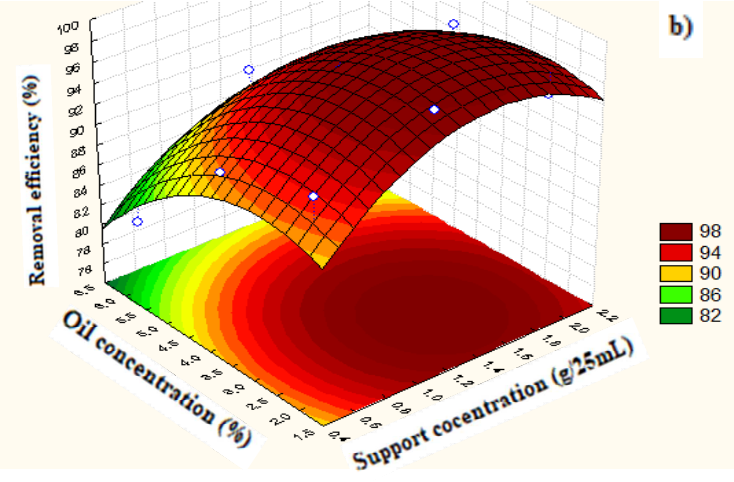

$$
\begin{gathered}
Z=25,86-35,42 x+78,72 x^{2}+279,41 y+18,2 y^{2}+954,04 x \cdot y-65,26 \\
x \cdot y^{2}-99,58 \cdot x^{2} \cdot y+137,68 x^{2} \cdot y^{2}
\end{gathered}
$$

Figure 3 - The response surface of the percentage of removal $(\%)$ as a function of contaminant concentration versus concentration of purified sugarcane bagasse (a) and calcined (b).

According to Figure 3 (a), the interaction of the contaminant concentration with the concentration of the purified sugarcane bagasse as a function of the removal response variable $(\%)$ presented an optimum region comprised between the entire concentration region (4-8\%) and the range of support concentration between 1 and $1.8(\mathrm{~g} / 25 \mathrm{~mL})$ with removal values close to $95 \%$. At concentrations above this value a drop in the percentage of removal may be observed due to the competitive effect of the carrier particles. Similar behavior was observed when using the sugarcane bagasse in calcined in natura - Figure 3 (b). In addition, the highest removal percentage values were observed when compared to purified in natura, with a greater range of use. Figures 4 (a) and 4 (b) show, respectively, the mapping of the systems using purified and calcined rice bagasse.

a)

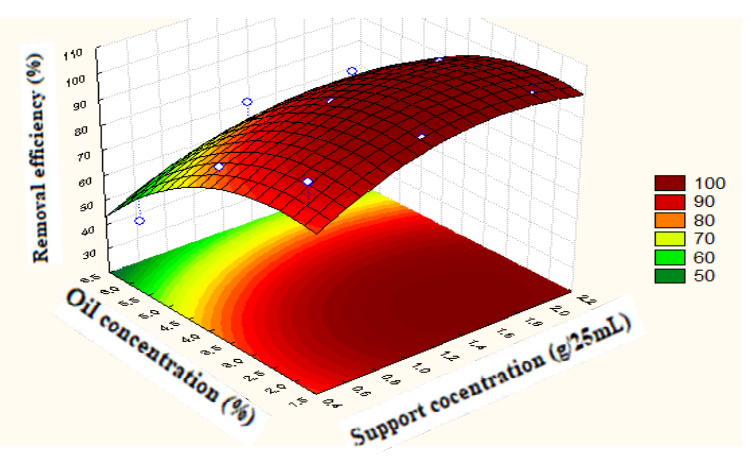

$$
\begin{gathered}
Z=39,86-335,42 x+2,72 x^{2}+279,41 y+48,62 y^{2}+954,04 x \cdot y- \\
165,26 x \cdot y^{2}-99,58 \cdot x^{2} \cdot y+137,68 x^{2} \cdot y^{2}
\end{gathered}
$$




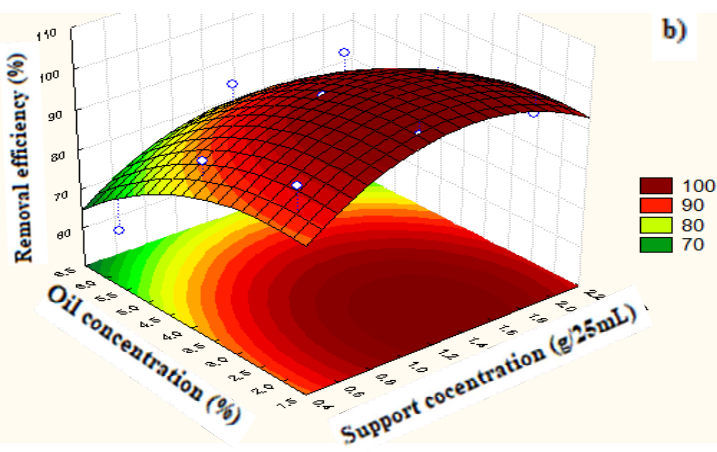

$Z=21,86-335,42 x+28,72 x^{2}+79,41 y+14,62 y^{2}+954,04 x . y-$ $15,26 x \cdot y^{2}-99,58 \cdot x^{2} \cdot y+37,68 x^{2} \cdot y^{2}$

Figure 4 - The response surface of the removal percentage $(\%)$ as a function of the contaminant concentration versus the concentration of the purified rice bagasse (a) and calcined (b).

According to the curves shown in Figure 4 (a) and 4 (b), the interaction of the contaminant concentration with the rice bagasse concentration occurs at practically all levels of support concentration. However, an optimal region between 1 and $1.8(\mathrm{~g} / 25 \mathrm{~mL})$ for the carrier concentration and 2 to $4(\%)$ for the region inherent to the oil concentration were responsible for promoting maximum removal efficiency $(98 \%)$.

\section{CONCLUSIONS}

According to the factorial modeling mapping, the interaction of the contaminant concentration with the concentration of the purified sugarcane bagasse as a function of the response variable removal (\%) presented an optimum region comprised between the entire concentration region of contaminant (4-8\%) and the range of support concentration between 1 and $1.8(\mathrm{~g} / 25 \mathrm{~mL})$ with removal values close to $97 \%$. At concentrations above this value, a drop in the percentage of removal can be observed, a fact justified by the competitive effect of the particles of the support.

The interaction of the contaminant concentration with the concentration of purified and calcined rice cake occurs at practically all support concentration levels. However, an optimal region between 1 and $1.8(\mathrm{~g} / 25 \mathrm{~mL})$ for the carrier concentration and 2 to $4(\%)$ for the region inherent to the oil concentration were responsible for promoting maximum removal efficiency $(98 \%)$.

The sugarcane bagasse and rice represent a promising potential for the removal of contaminants present in water produced from petroleum, in view of the reduction in approximately $98 \%$ of the oil present in the medium, suggesting that both supports represent an application promising in the advancement of technologies responsible for the treatment of water produced from petroleum.

\section{R E F E R E N C E S}

AHMADUN, Fakhru'l-Razia, et al. Review of technologies for oil and gas produced water treatment. JournalofHazardousMaterials, 530-551, 2009.

FREIRE, R.S.; PELEGRINI, R. KUBOTA, L. T.; DURÁN, $\mathrm{N}$. Novas tendências para o tratamento de resíduos industriais contendo espécies organocloradas. Curitiba/PR, 2000 .

FONSECA, L. P. Estudo das variáveis operacionais do processo de separação petróleo-água, utilizando flotação por ar dissolvido. Alagoas, 2010.

GOMIDE, R. Operações unitárias: operações de transferência de massa. $1^{a}$ ed.São Paulo: Dag Gráfica e Editora ltda., 1988.

IWAKI, G.P.; Sistemas de Tratamento de Água Produzida em Plataformas OFF-SHORE, 2015.

LUZ, A.D. Aplicação de processos adsortivos na remoção de processos adsortivos na remoção de compostos BTX presentes em efluentes petroquímicos. Florianópolis/SC, 2009.

PANDEY, N.; SHARMA, C.P. Effect of heavy $\mathrm{Co}^{2+}, \mathrm{Ni}^{2+}$ and $\mathrm{Cd}^{2+}$ on growth and metabolism of cabbage. 2002.

RODRIGUES, L.A., SILVA, M.L.C.P.An investigation of phosphate adsorption from aqueous solution onto hydrous niobium oxide prepared by co-precipitation method, Colloids and Surface A: Physicochem. Eng. Aspects (334) 191-196, 2009.

RUTHVEN, D. M. Principles of adsorption and adsorption process. United States of America: Wiley - Interscience Publication, 1984. 